(日本原子力研究所)

\title{
Overview of 1MW Pulse Neutron Source at J-PARC
}

Yujiro Ikeda

Japan Atomic Energy Research Institute

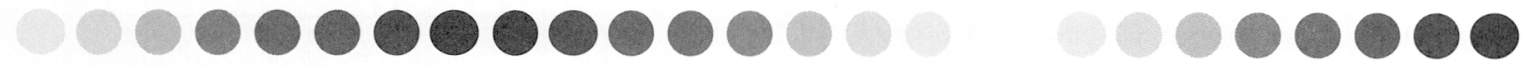

\begin{abstract}
The design status of the $1 \mathrm{MW}$ spallation neutron source (JSNS) in the J-PARC project is to be described with an emphasis of the particular features in terms of structural components which form the central part of target station. Also, this article is expected to give a guide of which following sections are treating in specific technical issues such as spallation reactions, moderator neutronics and its technology, and radiation shielding.

Keywords: J-PARC, IMW spallation neutron source, Overview, Technical issues
\end{abstract}

\section{J-PARC について}

J-PARC は原研が高エネルギー加速器研究機構 と共同で, 原研東海研究所内に建設している世界 最高の陽子ビーム強度をもつ加速器施設である。 $3 \mathrm{GeV}$ さらに $50 \mathrm{GeV}$ まで最大 $1 \mathrm{MW}$ のパワーで陽 子をパルス状に加速し, 標的原子核に衝突させて 中性子, 中間子などの発生する 2 次粒子を利用し, 原子核, 素粒子等の物理, 新物質, 材料, 生命科学 など, 最先端の研究を進める. 加速器は, 初段の $400 \mathrm{MeV}$ リニアック, $3 \mathrm{GeV}$ シンクロトロン, 及び $50 \mathrm{GeV}$ シンクロトロンで構成され, $3 \mathrm{GeV}, 1 \mathrm{MW}$ 陽 子を物質・生命科学実験施設に, $50 \mathrm{GeV}, 0.75 \mathrm{MW}$ の 陽子を原子核・素粒子実験施設及びニュートリノ 施設に導く.さらに, $400 \mathrm{MeV}$ リニアックに超 伝導加速器を追加し $600 \mathrm{MeV}$ 陽子を用いる核変換 実験施設が第 2 期計画で建設予定である. 複合加 速器と利用施設をうまく組み合わせた多目的一体 施設として世界的に例のない試みである. Fig. 1 に 完成時に予想される施設全体の鳥瞰イメージを示 于.

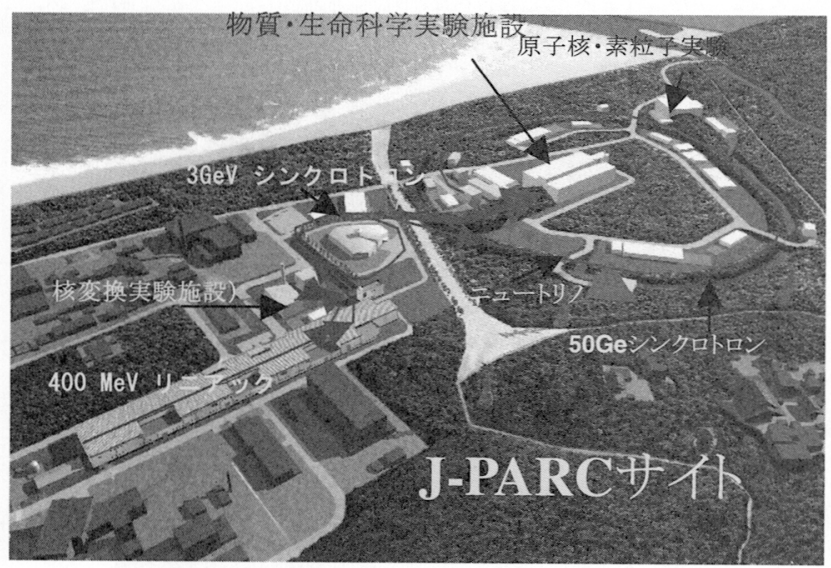

Fig. 1 Bird's eye view of J-PARC facilities.
J-PARC の建設は平成 13 年度から始まり, 平成 19 年度の完成, 20 年度からの施設共用開始を予定 している。既に，プロジェクトチームの提案を含 めて国内外から多くの利用実験装置設置希望があ り，その性能，規模に世界が注目している。

\section{J-PARC 中性子源の性能}

J-PARC の中心的な共用施設となる物質・生命科 学実験施設は $1 \mathrm{MW}$ パルス核破砕中性子源とミュ オンターゲットが置かれ，中性子とミュオンが同 時に利用できる。ここで実現するパルス中性子源 (JSNS)の性能は, 既存の加速器中性子源 ISIS と比 ベて 1 桁近い高い強度, 原子炉中性子源 ILL と比 ベて時間積分強度は及ばないがパルスのピーク強 度では 2 桁高い。また, 現在米国で建設中の $1.4 \mathrm{MW}$ 出力の SNS と比べて, 出力は $1 \mathrm{MW}$ と低い が，パルス周波数は $25 \mathrm{~Hz}$ で SNS の $60 \mathrm{~Hz}$ より低い ことから JSNS がパルス当たり 1.7 倍強い. 積分強 度においても, モデレータ配置の違いにより SNS より 1.4 倍強いもので, 世界最高の性能である. 最 大の売り物は, 世界最強となるパルス強度と $25 \mathrm{~Hz}$ 運転による広いバンド幅の利用で見える対 象の運動領域の拡大である.

\section{3. 重要な設計概念}

JSNS の設計の詳細については技術設計書を参 照されたい. [1] ここでは, JSNSの性能を高める ために採用した基本概念を紹介寸る。また中性子 特性に関わる部分については, 引き続く章で具体 的な記述がある。設計概念を構築する視点として, 施設安全は基より, 材料, 熱, 核反応, そして良好 な利用環境の確保がある。可能な限り, 概念のべ 一スとなる判断, 基準などを示す. 
3.1 中性子源の全体機器構成, 構造

まずは中性子源構成機器の構造概念の理解のた めに Fig. 2 をみてみよう。これは, 現在の J-PARC/JSNS 製作設計図そのものから作成した 3 次元 CAD イメージである. 全体は高さと直径が ほぼ同じ長さの円筒形をしている. 中性子を発生 するターゲットはほぼ中央に位置し, そこに $25 \mathrm{~Hz}$ のパルス状の陽子ビームが水平に入射する. ターゲット材料は循環する水銀で, エネルギー $3 \mathrm{GeV}$ の陽子との核破砕反応で陽子 1 個当たり約 60 個の中性子が発生する. 発生した中性子のエネ ルギーを利用に適したエネルギーに反射減速する モデレータがターゲットの上に 2 台と下に 1 台配 置される。モデレータに入る中性子を増や寸ため のモデレータの周りを反射体で囲む.さらにその 外側に鉄の遮蔽体を円筒状に巻き, ステンレス製 のヘリウムベッセルに納める. ベッセルの外側に は生体遮蔽の鉄ブロックを主とした材料でほぼ満 たされる. モデレータからの中性子はそこを基点 として放射状に最大 23 本の中性子ビームライン の数として取り出される. 中性子ビーム老必要に 応じて上下駆動で遮断するシャッターは生体者遮 蔽体の中に設置される.陽子ビーム空は陽子ビー ム導入管とヘリウムベッセルの接合部に置かれ, 真空境界およびヘリウムシールを兼称ると共に, 陽子ビームモニターとして機能する. 全体を収納 する外側容器は直径約 $10 \mathrm{~m}$ の円筒形鉄ライナー である。このライナーの外周は，さらに生体遮蔽 として厚さ $2 \mathrm{~m}$ 以上の重コンクリートで覆われる. Table 1 に構成機器の主要パラメータを示す. 以上 が主要機器の基本構成であるが, それぞれの設計 思想について，ポイントを紹介する。

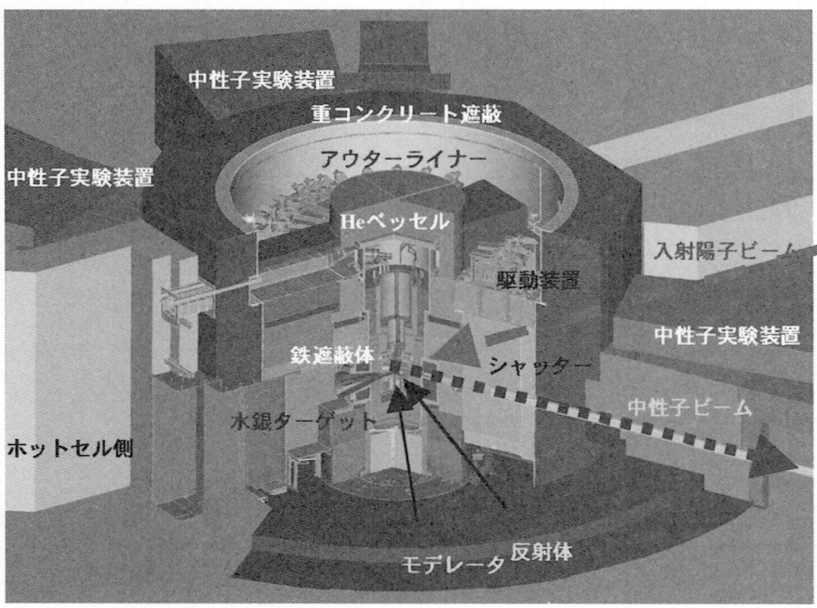

Fig. 2 3D image of the JSNS target station. All components are drawn based on the current design. The target cart, and some of the neutron instruments are removed from the figure.
Table 1 Major parameters of the 1MW pulse neutron source target station

\begin{tabular}{|c|c|}
\hline Parameter & Base Value \\
\hline \multicolumn{2}{|l|}{ TARGET SYSTEMS } \\
\hline Design power level on target & $1 \mathrm{MW}$ \\
\hline Number of neutron beam lines & 23 \\
\hline Energy of proton beam & $3 \mathrm{GeV}$ \\
\hline Beam current & $0.3 \mathrm{~mA}$ \\
\hline Repetition rate & $25 \mathrm{~Hz}$ \\
\hline Pulse width & $<1 \mu \mathrm{s}$ \\
\hline \multicolumn{2}{|l|}{ TARGET ASSEMBLIES } \\
\hline Front cross section of target $\mathrm{VxH}^{*}$ & $96 \times 192 \mathrm{~mm}$ \\
\hline Beam spot size on target $\mathrm{VxH}$ & $70 \times 184 \mathrm{~mm}$ \\
\hline Normal peak current density & $10 \mu \mathrm{A}$ \\
\hline Target material & $\mathrm{Hg}$ \\
\hline $\mathrm{Hg}$ operating temperature & $119^{\circ} \mathrm{C}$ \\
\hline $\mathrm{Hg}$ target operating pressure & $0.5 \mathrm{MPa}$ \\
\hline $\mathrm{Hg}$ power loading & $0.5 \mathrm{MW}$ \\
\hline Shell material & SS-316LN \\
\hline Shroud cooling & SS-316LN \\
\hline \multicolumn{2}{|l|}{ MODERATORS } \\
\hline Number of moderators & 3 \\
\hline Type of moderator & $\begin{array}{l}\text { Coupled } 1 \\
\text { Decoupled } 1 \\
\text { Poisoned } 1\end{array}$ \\
\hline Moderator material & $\mathrm{H}_{2}$ \\
\hline Viewed face & $100 \times 100 \mathrm{~mm}^{2}$ \\
\hline Pre moderator & $\mathrm{H}_{2} \mathrm{O}$ \\
\hline Container material & A6061-T6 \\
\hline Decoupler & Al clad AIC \\
\hline Poison material & $\mathrm{Al}$ clad $\mathrm{Cd}$ \\
\hline \multicolumn{2}{|l|}{ REFLECTOR } \\
\hline Reflector material & $\mathrm{Be}$ (in), $\mathrm{Fe}$ (out) \\
\hline Container material & A5083-o \\
\hline Configuration & Nested cylinder \\
\hline Coolant & $\mathrm{D}_{2} \mathrm{O}$ \\
\hline Height & $1.2 \mathrm{~m}$ \\
\hline \multicolumn{2}{|l|}{ HELIUM VESSEL } \\
\hline Material & SS-316 \\
\hline Atmosphere & $\mathrm{He}$ \\
\hline Proton beam window material & A5083-o \\
\hline Proton beam window coolant & $\mathrm{H}_{2} \mathrm{O}$ \\
\hline \multicolumn{2}{|l|}{ SHUTTER SYSTEM } \\
\hline Number of single channel shutters & 23 \\
\hline material & SS /Concrete \\
\hline Drive system & Electrical \\
\hline open/close position & Lowest close \\
\hline \multicolumn{2}{|l|}{ CRYOGENIC SYSTEM } \\
\hline Total H2 inventory & $0.256 \mathrm{~m}^{3}$ \\
\hline Flow configuration for moderators & Parallel \\
\hline Number of $\mathrm{H} 2$ circulators & 2 \\
\hline Moderator in/out temperature & $18 \mathrm{~K} / 21 \mathrm{~K}$ \\
\hline Moderator supply pressure & $1.5 \mathrm{MPa}$ \\
\hline Ortho Para converter & Yes \\
\hline Pressure control system & Yes \\
\hline
\end{tabular}


3.2 核破砕水銀ターゲット

ターゲット材料として水銀を採用した. 固体タ ーゲットは $1 \mathrm{MW}$ のパルスビーム入射による熱応 力で破壊されるため, 採用できないためだ. 循環 水銀をターゲットとし熱は熱交換機で除去するこ とで熱的システムとして成立する. 流動性により, 必要に応じてダンプタンクに待避させ局所的な保 管管理が可能であることから, ターゲット容器の 交換時の放射線被爆は, 固体ターゲットと比べて 格段に少ない.すなわち積極的な放射線の管理が メリットとなる，さらに，多くの中性子を生産す る観点では, 核破砕反応での中性子の収率は原子 番号の大きな物質ほど大きいので水銀が適してい る.一方, 液体水銀であることから生ずる克服す べき課題がある. 液体の熱膨張による圧力波に対 する設計, 水銀の循環に関わる閉じこめ技術の経 験不足による未熟さである. 圧力波に関しては, BNL の AGS 加速器を用いた実規模大の水銀模擬 ターゲットによる実験で, 圧力波を実験的に測定 すると共に, その実験解析から設計評価の妥当性 についておおよその検証が達成された。しかしな がら, 圧力波のオフライン実験の中で, 圧力波が 起因する容器内面に生ずるピッティングが新たな, しかも重大な対処が必要な事象として観測された. この問題は, 容器寿命に直結するため, 現象解明 と対処方法の検討, 試験を継続している. 米国 SNS も同様に水銀をターゲットとする設計で共通 の課題であることが認識され, 米国 LANLの WNR 施設を用いた陽子ビーム入射実験を行った。 その結果, ピッティングが同様に観測され，この 問題が現実的な対応を迫られるきわめて重大なも のとして提起された. その後, 日米協力して集中 的な検討努力を続けている. 陽子ビーム実験は回 数に制限があり，多くの情報を系統的に収集する には難しいことから，プロジェクトチームは圧力 波とそれに伴うキャビテーションを模擬できる電 磁衝撃試験器を開発し系統的な実験を開始した. パルス衝撃（電磁衝撃）のサイクル数の増加とと もにピッティングによる容器材料表面の浸食が進 み状態が変化する. サイクル数が 100 万回を超す と一気に表面が削られてゆくことが観測された。 現在も実験を継続し, 硬化処理等の表面改質とと もに，圧力波そのものを下げる方法など $1 \mathrm{MW} に$ 到達するまでに行うべき技術開発に取り組んでい る。

Table 2 Representative neutron flux from each moderator

\begin{tabular}{|l|c|r|r|c|}
\hline Type of Moderator & $\begin{array}{c}\text { Number of } \\
\text { Beam Ports }\end{array}$ & $\begin{array}{c}\text { Time-integrated } \\
\text { Thermal Neutron } \\
\text { Flux [n/s.cm }]^{2}\end{array}$ & $\begin{array}{c}\text { Peak Neutron } \\
\text { Flux at 10 meV } \\
\left.[\mathrm{n} / \mathrm{eV} . \mathrm{s.cm}]^{2}\right]^{*}\end{array}$ & $\begin{array}{c}\text { Pulse Width } \\
\text { in FWHM at } \\
10 \mathrm{meV}[\mathrm{us}]\end{array}$ \\
\hline \hline Coupled Moderator & 11 & $4.6 \times 10^{8}$ & $6.0 \times 10^{12}$ & 92 \\
\hline Decoupled Moderator & 6 & $0.95 \times 10^{8}$ & $3.0 \times 10^{12}$ & 33 \\
\hline $\begin{array}{l}\text { Poisoned Moderator } \\
\text { (Thicker Side) }\end{array}$ & 3 & $0.65 \times 10^{8}$ & $2.4 \times 10^{12}$ & 22 \\
\hline $\begin{array}{l}\text { Poisoned Moderator } \\
\text { (Thinner Side) }\end{array}$ & 3 & $0.38 \times 10^{8}$ & $1.4 \times 10^{12}$ & 14 \\
\hline
\end{tabular}

"Values at $10 \mathrm{~m}$ from the moderators
3.3 モデレータと反射体

JSNS のモデレータ設計では，ユーザーが望む 中性子を如何に効率的に引き出すかを常に念頭に 置き進めている．モデレータの性能が中性子源の 性能といっても過言ではない.

- 超臨界水素（20K, $1.5 \mathrm{MPa}$ )をモデレータ材料と して選択した。 これは, 超臨界水素が $1 \mathrm{MW}$ の核 破砕中性子の核発熱負荷に耐えられる材料で最も 水素数密度が高いことが理由である.

-中性子特性の異なる 3 種類のタイプのモデレー タを備えることとした．結合型モデレータでは， 時間積分強度を高め, しかも最も多くの利用要求 を満たすために, 初めての試みとして円柱型の容 器構造を採用した. さらにパラ水素の中性子反応 特性を生かし, 最適な体積を導出し, 1 台の容器 で合計 11 本のビームラインで強度の偏りのない 中性子ビームを享受できるようにできたことを特 筆しておきたい. また, 米国の SNS の $2 \mathrm{MW}$ 相当 の強度の比較において, $1 \mathrm{MW}$ の JSNS は同等の性 能を達成している。これは, JSNS での単独配置広 角度取り出しのアイデアが優れているところと言 える。（SNS では隣接する非結合モデレータによ る中性子吸収が結合型モデレータの強度低下を招 いている.)

・低エネルギー側を抑制し，時間分解能を高めた 非結合型 (デカップル) モデレータでは, $1 \mathrm{eV}$ と高 いデカップリングエネルギーを実現できる AIC 合 金デカップラーに着目し，技術開発を精力的に進 め, 実機製作の見通しを得た。これは低出力中性 子源では通常用いられてきたボロンのデカップラ 一が $1 \mathrm{MW}$ では材料として成立困難なことを受け て行った開発の成果である。しかしながら，AIC に含まれる銀が生成する高い誘導放射能の取り扱 いのため, 大型の遮蔽キャスクとそれをプラグと 共に移動させる重量クレーン設備が必要となった ことは，ネガティブな要素であった．最終的にモ デレータの性能を優先させる判断をした．さらに, 時間分解能要求に対応するポイズンドモデレータ では, $\mathrm{Cd}$ をその材料とする設計が完了した。

・モデレータの容器材料は低温での中性子照射損 傷特性に優れている A6061 を用い, 容器は低温水 素の循環, 外側容器の冷却, 水素漏洩対策のため の 4 - 5 重の容器, 配管構造とした. Table 2 に 
中性子源性能の目安となるモデレータから $10 \mathrm{~m}$ 位置での時間平均での中性子束の值を示す。モデ レータ中性子特性, 及びモデレータ設計の詳細に ついては，それぞれ別の章で詳しく述べられる。

・反射体材料として中性子減速能の高いベリリウ ムを採用した。これは初期に検討した鉛が, 溶融 という問題があることが判明したためである。

\section{4 遮蔽体，シャッター}

発生する中性子を適切に遮蔽し周辺への放射線 線量を実験者や運転保守要員に対する影響をなく すために中性子源遮蔽設計を行っている. $3 \mathrm{GeV}$ ら熱中性子までの広いエネルギーの中性子を効果 的に遮蔽するために JSNS ではターゲットを中心 として主として鉄（約 $4.5 \mathrm{~m}$ 厚さ），その外側に 重コンクリート（約 $2 \mathrm{~m}$ 厚さ）を設けている. 設 計の基本指針, 詳細な技術検討, 評価は, 続く遮 蔽計算の章で取り上げられるので説明を省く。

\section{5 ビームライン実験装置の配置}

Fig. 3 にJ-PARC 物質・生命科学実験施設の 1 階 部分の鳥瞰図を示す. JSNS を中心として現在プロ ジェクトチームが設置を計画している装置の配置 をしてみた，全てのモデレータは両面から取

り出されるので中性子源中心に陽子ビーム入射方 向に対して角度約40度から 140 度の範囲で左右に 放射状に装置ラインが延びている。中性子ビーム ラインの数は, 周辺に置かれる実験装置の想定,
見込むモデレータの種類, 隣り合うビームライン と幾何学的干渉, 構造体の強度, さらにビームを 遮断するシャッターの構造と駆動装置設置条件な どを考慮して 23 本と決定した。

\section{4. 今後の展開}

我々の，これまでに検討で，技術，コスト，稼働 率, 利用効率, 安全性等, 全体的な施設のあり方 を総合的に評価すれば, $1 \mathrm{MW}$ パワーは既に限界に 近い技術対象と判断せざるを得ない。これすらも， 挑戦的な気の抜くことが許されないかなりしんど い事業であることを実感している。まずは，施設 建設の完成を着実に目指して行きたい.

\section{参考文献}

[1] 大強度陽子加速器プロジェクト, 物質・生命科 学実験施設機器技術設計書, JAERI-Tech 2004-001.

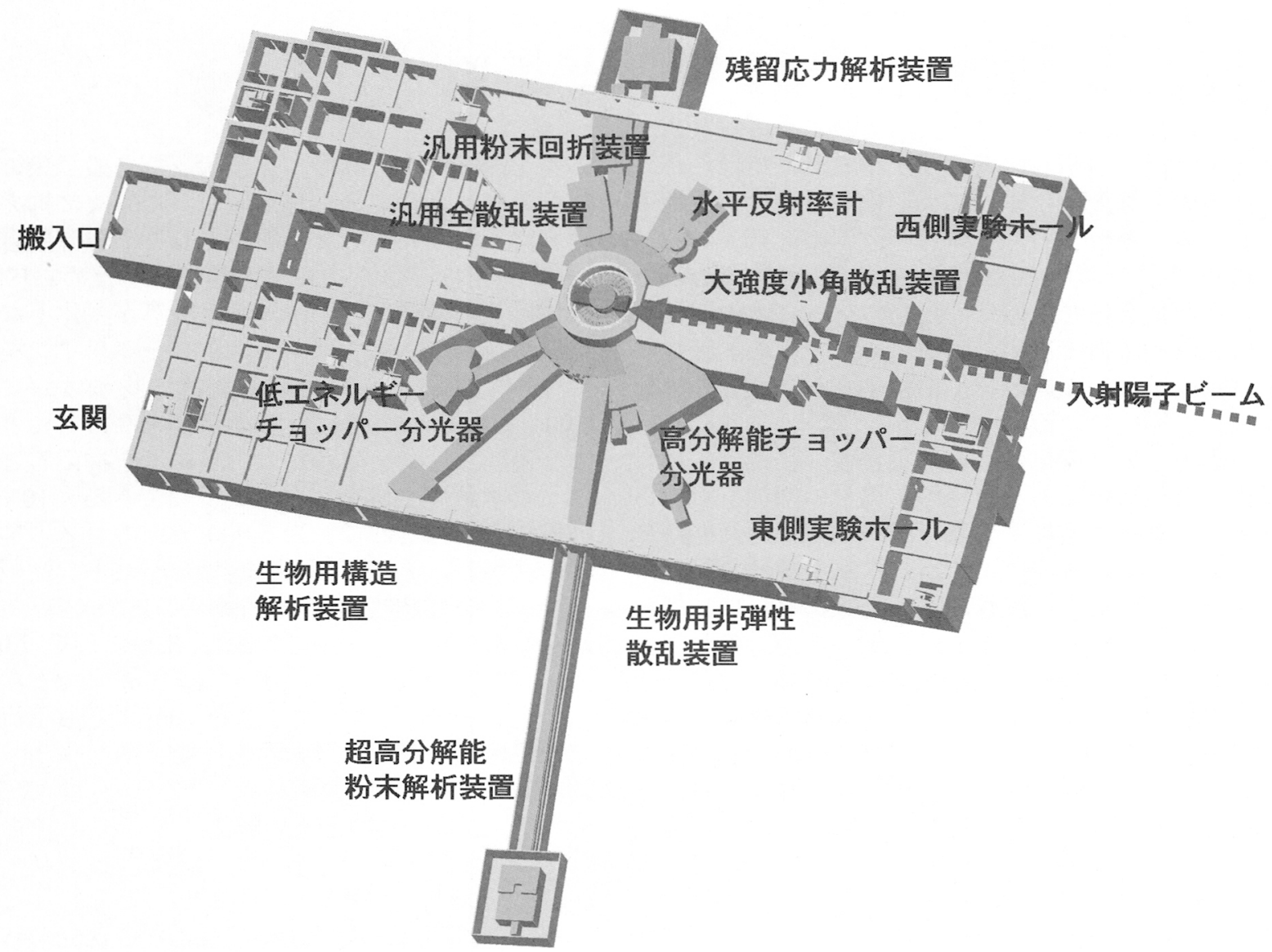

Fig. 3 View of the first floor of Materials \& Life Experimental Facility. JSNS is located at the center. 